\title{
Toxic heavy metal biosorption by some marine bacteria isolated from the sediments of industrial effluents of Iligan Bay
}

\author{
Arvin C. Balala' and Jose M. Oclarit ${ }^{2}$ \\ ' Department of Biological Sciences, Visayas State University (formerly Leyte State \\ University), Baybay City, Leyte 6521-A, Philippines; ${ }^{2}$ Laboratory of Applied \\ Biochemistry and Molecular Biology, Mindanao State University-Iligan Institute of \\ Technology, Iligan City, Philippines
}

\section{ABSTRACT}

Heavy metal-resistant marine bacteria were isolated from the sediments of Iligan Bay near the effluents outlets of certain factories. Isolation was done using marine agar fortified with corresponding different heavy metal concentrations. Isolates were grouped using their morphological and colonial growth characteristics. Among the purified isolates(61), 19 were cadmium-resistant, 29 were lead-resistant and 13 were mercuryresistant. These isolates were tested for their absorptive capability using marine broth added with metal ions: $23.20 \mu \mathrm{g}$ of $\mathrm{Cd}, 250.24 \mu \mathrm{g}$ of $\mathrm{Pb}$ and $495.66 \mu \mathrm{g}$ of $\mathrm{Hg}$, and consequently analyzed using Atomic Absorption Spectrophotometric(AAS) method. From these isolates, 10 heavy metal-resistant species with relatively high absorptive efficiency were identified using conventional method and API 20E Test Kit. Out of ten isolates, 3 were Gram-positive and 7 were Gram-negative rods. All Gram-positive bacteria belong to the genus Bacillus and were found to absorb lead metals at $94 \%$ absorptive efficiency. However, Enterobacter sp. 2 had the highest absorptive efficiency for Cd at 99\% among Gram negative bacteria followed by Chryseomonas sp. 2 with $96 \%$ biosorption. Furthermore, among the mercury resistant isolates, Pseudomonas sp. had the highest absorptive efficiency at $79 \%$. Only those heavy metal-resistant isolates which exhibited the highest absorptive efficiency were able to form a zone of growth promotion around a heavy metal-containing filter paper disk which suggests that these bacteria have accumulated heavy metals in their cells. The presence of heavy metalresistant bacteria is helpful in cleaning up or remediating metal contaminated environments released from industrial effluents.

Keywords: absorptive efficiency, zone of growth promotion, atomic absorption spectrophotometer, heavy metal-resistant bacteria 


\section{INTRODUCTION}

The expansion of industry, mining and modern agriculture has contributed to higher amounts of toxic metals in the environment. The accumulation of various metals poses potential threat to the health and well being of human life and desirable species.

Iligan City, considered as a highly industrialized city, hosts a number of industrial plants producing steel, ceramics and refractories, and vinyl chloride among others. As such, Iligan Bay has become a catch-basin to a wide variety of environmental pollutants including heavy metals from the industries as well as from agricultural and domestic sources.

With the awareness of the increasing release of toxic metals such as mercury $(\mathrm{Hg})$, lead $(\mathrm{Pb})$, and cadmium $(\mathrm{Cd})$ by industrial establishment and mining operations, it is imperative that research on finding ways to reduce toxic metal concentration in the environment be done. New biotechnological approaches are now being exploited for the biological treatment of these waste effluents and products.

The use of microorganisms, bacteria in particular, in the extraction and recovery of metals was one of the methods developed as early as 1940 (Mc Calla, 1940). Reported methods include biosorption that often involves the uptake of metals by microbial cells (Tesezos and Bell, 1989). Because microbial habitats are affected by high concentration of heavy metals, bacteria in particular have evolved several mechanisms to tolerate the presence of heavy metals by inducible ion efflux systems(Nies and Silver, 1995), complexation and reduction of metal ions to less toxic metal(Izaki et al., 1985). The use of microbial biomass to absorb toxic metals from aqueous industrial effluents and sludges offers an economical and convenient alternative to physicochemical techniques such as ion exchange activated carbon adsorption, electrolysis, and precipitation by sulfides and carbamates (Mamaril et al., 1993).

The present study isolated and purified heavy metal-resistant marine bacteria from the Iligan Bay sediments at the outflows of certain factories by growth in heavy metal-containing media. Further, it determined and compared the absorptive efficiency of the heavy metal-resistant bacteria for various heavy metals and determined the possible growth promotion or inhibition due to heavy metal absorption in the isolates with the highest absorptive efficiency. Finally, it identified the genera of heavy metal-resistant bacteria with the highest 
absorptive efficiency. The results of this study can be useful in solving the problem of heavy metal pollution in Iligan City through their recovery from effluents.

\section{MATERIALS AND METHODS}

\section{Collection and preparation of samples}

Samples were collected from the effluent outlets of industrial factories in Iligan City, namely: two common effluent outlet from Mabuhay Vinyl Corporation (MVC) and Maria Cristina Chemical Industries (MCCI) and National Steel Corporation (NSC) situated at the southern part of Iligan City. The other site was from Jacinto Colorsteel situated at Luga-it, Misamis Oriental in the northern part of Iligan Bay (Figure 1). Three subsampling stations were identified in each sampling site. Approximately 500 grams of composite sample of six sediment cores, $10 \mathrm{~cm}$ depth, were collected from the sampling site. Samples were sealed and protected from direct sunlight and transported directly to the Microbiology Research Laboratory of the Department of Biological Sciences of MSU-IIT. Ten (10) grams of sediment were obtained from 500 grams of composite sediment sample and was transferred to a sterile $150 \mathrm{ml}$ bottle with $90 \mathrm{ml}$ of $0.1 \%$ peptone. The mixture was mixed vigorously for 10 minutes to disperse the bacterium into suspension and to separate sediment particles. The suspension was set aside for 30 minutes to allow sediments to settle down.

\section{Isolation and enumeration of heavy metal-resistant bacteria}

Serial dilutions of up to $10^{-4}$ of sediment samples were done and $0.1 \mathrm{ml}$ aliquot of each dilution was spread-plated in MS agar plates with $10 \mu \mathrm{g} / \mathrm{ml}$, $20 \mu \mathrm{g} / \mathrm{ml}, 30 \mu \mathrm{g} / \mathrm{ml}, 40 \mu \mathrm{g} / \mathrm{ml}$ and $50 \mu \mathrm{g} / \mathrm{ml}$ concentrations of the heavy metal. The plates were incubated at $37^{\circ} \mathrm{C}$ for 24 hours and monitored every 6 hours. Different bacterial colonies were picked and streaked to MS agar and was repeated until pure cultures were obtained. Purified isolates were streaked in agar slant and maintained in the same medium at $10^{\circ} \mathrm{C}$ in the refrigerator. 


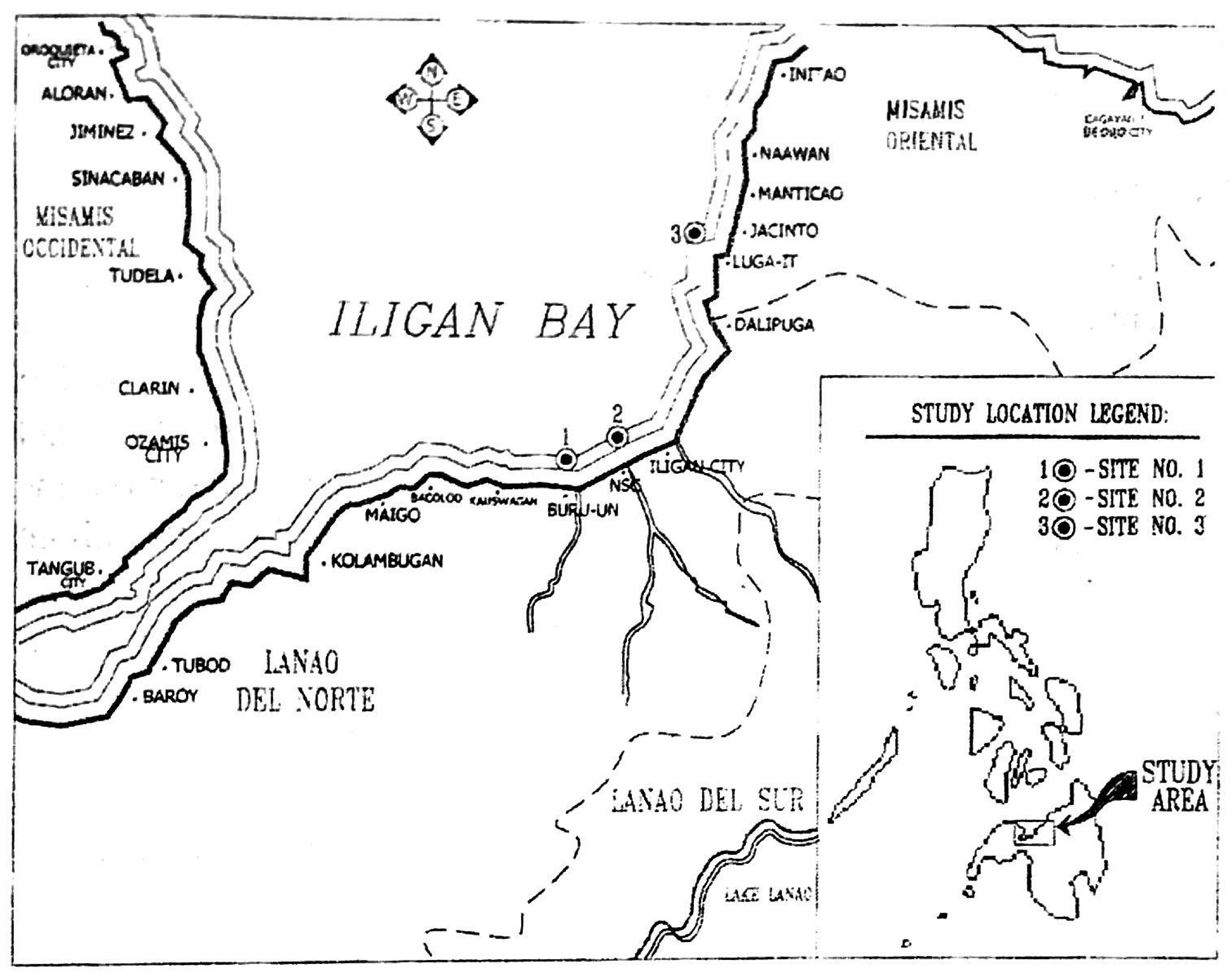

Figure 1. Map showing the three sampling sites in Iligan Bay 
The isolates were subjected to Gram staining to assess their Gram reaction, shape and the arrangement of the cells. These were also grown in thioglycollate agar to determine their oxygen requirement whether aerobe, anaerobe, facultative anaerobe or strict aerobe.

\section{Determination of absorptive efficiency}

Two set-ups, $A$ and $B$, were prepared for the determination of the concentration of metals ions $(\mathrm{Cd}, \mathrm{Pb}$, and $\mathrm{Hg})$ remaining in the broth after growth of the bacteria. Set-up A consisted of three tubes containing $10 \mathrm{ml}$ of MS broth with $1.5 \mu \mathrm{g} / \mathrm{ml}$ for cadmium nitrate $\mathrm{Cd}\left(\mathrm{NO}_{3}\right)_{2}, 10 \mu \mathrm{g} / \mathrm{ml}$ for lead nitrate $\mathrm{Pb}\left(\mathrm{NO}_{3}\right)_{2}$ and $50 \mu \mathrm{g} / \mathrm{ml}$ for mercuric chloride $\left(\mathrm{HgCl}_{2}\right)$. Set-up Bis the control which consisted of three tubes containing $10 \mathrm{ml}$ of MS broth without the heavy metals. Two loopfuls of isolate were transferred to $2 \mathrm{ml}$ of sterile $0.6 \%$ saline solution and was shaken to disperse the bacterium. Set-up $A$ and B were both inoculated with $100 \mu \mathrm{l}$ of the bacterial suspension per tube in order to have a uniform inoculum. The tubes were incubated for 48 hours at room temperature. After incubation period, the broth was centrifuge at 5,000 rpm for 15 minutes. The supernatant was pipetted and subsequently analyzed for cadmium, lead and mercury.

\section{Digestion of samples for heavy metal analysis}

In a 250-ml boiling flask, approximately $10 \mathrm{ml}$ of the supernatant broth sample was added with $1 \mathrm{ml}$ of concentrated $\mathrm{H}_{2} \mathrm{SO}_{4}(1: 1)$ and $0.35 \mathrm{~g}$ of $\mathrm{KMnO}_{4}$. Digestion of the sample at the boiling temperature was maintained for 1.5-2 hours. The digested sample was allowed to cool before the dropwise addition of hydroxyl ammonium chloride until a clear and colorless solution without precipitate was obtained. Dilution of the sample to $25-\mathrm{ml} \mathrm{mark}$ in the volumetric flask was done with deionized water. Standard solutions at different concentrations of the metals were digested similarly that of the sample.

\section{Standard calibration curve}

The absorbance of the different concentrations of the standard digest solutions were determined using an atomic absorption spectrophotometer 
Thermo Jarrel Ash-AA SCAN. A linear plot of the absorbance versus concentration of the standard solution was obtained for each metal with a correlation coefficient of the range 0.9907-0.9997. From the standard calibration curve, the concentration of the metal in the sample was determined. The AAS analyses for $\mathrm{Pb}$ and $\mathrm{Cd}$ were done by direct-air acetylene flame method while $\mathrm{Hg}$ was analyzed using the cold-vapor AAS method.

\section{Determination of the heavy metal uptake}

The amount of metal uptake by the bacteria was determined from the metal concentration that remained in the supernatant broth. Absorptive efficiency was calculated according to the following formula:

Absorptive efficiency $=\frac{M_{1}-M_{s}}{-M_{1}}$

where: $M_{1}=$ amount of heavy metal initially present in the culture broth before bacterial incubation. $\mathrm{M}_{\mathrm{S}}=$ amount of heavy metal left in the culture broth supernatant after 48 hours of bacterial incubation. $=\mathrm{M}_{\mathrm{CBM}}-\mathrm{M}_{\mathrm{CB}}$ where: $\mathrm{M}_{\mathrm{CBM}}=$ amount of heavy metal in culture broth supplemented with heavy metal.

$\mathrm{M}_{\mathrm{CB}}$ = amount of heavy metal in culture broth not supplementedwith heavy metal.

\section{Identification of heavy metal-resistant bacteria}

Bacterial isolates that have the highest absorptive efficiency were identified. Identification of bacteria was done using the API 20E for Gram-negative rods and cocci. The Gram-positive rods were identified based on their morphology and presence of spores. 


\section{Growth promotion/inhibition experiment}

To gain some insights on the mechanism of heavy metal resistance, a growth promotion/inhibition expetiment was performed. The filter paper disc diffusion method(Bauer et al., 1966) of testing was used, with filter paper disc either being impregnated or not impregnated with the heavy metal.

\section{Preparation of seeded agar assay plate}

Twenty four-hour culture of the bacterial isolates and selected bacterial species (E. coli and B. subtilis) on MS agar slants were prepared. Top agar was prepared by weighing $0.1 \mathrm{~g}$ of plain agar and $0.12 \mathrm{~g}$ of $\mathrm{NaCl}$, mixing in a $50 \mathrm{ml}$ flask containing $20 \mathrm{ml}$ of deionized water and autoclaved. To every individual top agar solution, two loopfuls of inoculum from each of the MS agar slant cultures were aseptically transferred. Vigorous shaking by hand homogenized the suspension. The seeded top agar was pipetted into each of the respective metal-less MS agar plates at equal amount of $2.5 \mathrm{ml}$ per plate. The inocula were spread by slight rotation of the plate.

\section{Preparation of impregnated paper disc}

Sterile disc made of Whatman filter paper No. 3 with a diameter of $1 \mathrm{~cm}$ was impregnated with $100 \mu \mathrm{L}$ of $1.5 \mu \mathrm{g} / \mathrm{ml}$ for cadmium nitrate $\mathrm{Cd}\left(\mathrm{NO}_{3}\right)_{2}, 10$ $\mu \mathrm{g} / \mathrm{ml}$ for lead nitrate $\mathrm{Pb}\left(\mathrm{NO}_{3}\right)_{2}$, and $50 \mu \mathrm{g} / \mathrm{ml}$ for mercuric chloride $\left(\mathrm{HgCl}_{2}\right)$ and was allowed to dry. With the use of a pair of sterile forceps, the dried impregnated disc was placed at the center of a properly labeled plate overlaid with the seeded top agar. The plates were incubated for 24 hours and the zones of growth promotion or inhibition were observed.

\section{RESULTS AND DISCUSSION}

\section{Isolated heavy metal-resistant bacteria}

A total of 186 bacterial isolates were purified and transferred to agar slants with the same concentration of the heavy metal and stored in the 
refrigerator. The 186 bacterial isolates were reduced to 61 isolates because of the removal of duplications as determined from their morphological and growth characteristics. Of the 61 purified isolates, 19 were cadmium-resistant, 29 were lead-resistant and 13 were mercury-resistant. Cadmium and mercury resistance in bacteria was known to be mediated by a plasmid(Nakahara ét al., 1977, Witte et al., 1986). It is conferred by 2 separate genes, designated as CAD A and CAD B (Perry and Silver, 1982). Microbial resistance to lead as well as mercury may occur via detoxification mechanisms such as biomethylation (Crais and Wood, 1991). Hydrogen sulfides in particular may play a key role in the biological cycle of mercury and lead by volatilization and precipitation. The absorptive capability of the 61 heavy metal-resistant isolates were determined using the Atomic Absorption Spectrophotometric(AAS) method. This showed which isolate is more efficient in metal uptake.

\section{Cadmium uptake}

The absorptive efficiency of 19 cadmium resistant bacterial isolates are shown in Table 1. The total amount of Cd ion in the marine broth was 23.20 $\mu \mathrm{g}$. Bacterial isolate from NSC (CN3 S 250) which had grown in $50 \mathrm{ppm}$ of $\mathrm{Cd}\left(\mathrm{NO}_{3}\right)_{2}$ has the highest value of absorptive efficiency $(99 \%)$ with an amount of $23.40 \mu \mathrm{g}$ of metal absorbed by the isolate followed by isolates from MVC/ MCCI (CM1 \& CM6 S 210) which had 96\% and 76\% absorptive efficiency, respectively. However, bacterial isolates from Jacinto Colorsteel had only $51 \%$ as the highest value of absorptive efficiency. The lowest absorptive efficiency for cadmium is $8 \%$ shown by bacterial isolate CM $16 \mathrm{~S} 220$ from MVC/MCCI with only $1.90 \mu \mathrm{g}$ of metal ion is absorbed. The removal of Cd from the medium is indicative of $\mathrm{Cd}$ accumulation inside the bacterial cell. More specifically, Gram-negative bacteria are highly resistant to $\mathrm{Cd}^{2+}$ ions and accumulated great amounts of Cd during growth (Nies and Silver, 1995). Furthermore, Cd uptake in Gram negative bacteria could be through the action of proton-cation anti-porters.

\section{Lead uptake}

Table 2 shows the absorptive efficiency of 29 lead-resistant bacterial isolates. Seven lead-resistant isolates had more than $80 \%$ absorptive efficiency 
Table 1. Summary of results on the absorptive efficiency of cadmium-resistant bacterial isolates grown in MS agar with different concentration ( $\mathrm{ppm}$ ) obtained from marine sediments of Iligan Bay

\begin{tabular}{|c|c|c|c|c|c|}
\hline $\begin{array}{c}\text { Heavy metal } \\
\text { concentration } \\
\mathrm{Cd}\left(\mathrm{NO}_{3}\right)_{2} \text { in } \\
\mathrm{mg} / \mathrm{ml}_{3} \mathrm{MS} \\
\text { agar used }\end{array}$ & $\begin{array}{l}\text { Heavy metal- } \\
\text { resistant } \\
\text { bacterial Isolate }\end{array}$ & $\begin{array}{c}\text { Total amount } \\
\text { of } C d(\mu \mathrm{g}) \text { in } \\
\text { culture broth } \\
\text { at start }\end{array}$ & $\begin{array}{c}\text { Amount of } \\
\text { Cd left in } \\
\text { culture broth } \\
\text { in } \mu \mathrm{g} \\
\left(\mathrm{M}_{\mathrm{CBM}}-\mathrm{M}_{\mathrm{CB}}\right)\end{array}$ & $\begin{array}{c}\text { Amount of } \\
\text { metal absorbed } \\
\text { by the } \\
\text { bacterial isolate } \\
(\mu \mathrm{g})\end{array}$ & $\begin{array}{c}\text { Absorptive } \\
\text { efficiency } \\
(\%)\end{array}$ \\
\hline \multirow{4}{*}{10} & $\mathrm{MVC} / \mathrm{MCCI}$ & & & & \\
\hline & CM 1 S $210^{*}$ & 23.20 & 0.81 & 22.40 & 96 \\
\hline & CM 5 S $210^{*}$ & 23.20 & 14.60 & 8.60 & 37 \\
\hline & CM 6 S 210* & 23.20 & 5.40 & 17.80 & 76 \\
\hline & CM 7 S $210^{*}$ & 23.20 & 18.21 & 5.00 & 21 \\
\hline \multirow[t]{2}{*}{20} & $\mathrm{CM} 11 \mathrm{~S} 220^{*}$ & 23.20 & 15.33 & 7.90 & 33 \\
\hline & CM 16 S 220* & 23.20 & 21.30 & 1.90 & 8 \\
\hline 30 & CM 20 S $230^{*}$ & 23.20 & 9.80 & 13.40 & 57 \\
\hline \multirow[t]{2}{*}{40} & CM 26 S 240* & 23.20 & 9.4 & 13.80 & 59 \\
\hline & NSC & & & & \\
\hline 10 & CN $1 \mathrm{~S} 310^{* *}$ & 23.20 & 12.10 & 11.10 & 47 \\
\hline \multirow[t]{3}{*}{20} & CN $1 \mathrm{~S} 320^{* *}$ & 23.20 & 12.73 & 10.47 & 45 \\
\hline & CN 3 S 220** & 23.20 & 6.73 & 16.47 & 70 \\
\hline & CN 4 S $320^{* *}$ & 23.20 & 14.35 & 8.85 & 38 \\
\hline 30 & $\mathrm{CN} 1 \mathrm{~S} 230^{*}$ & 23.20 & 11.20 & 12.00 & 51 \\
\hline \multirow[t]{2}{*}{50} & CN 3 S 250* & 23.20 & 0.07 & 23.13 & 99. \\
\hline & Jacinto Colorsteel & & & & \\
\hline 10 & CJ 2 S $210^{*}$ & 23.20 & 11.15 & 12.05 & 51 \\
\hline 20 & CJ 6 S $220^{*}$ & 23.20 & 15.05 & 8.15 & 35 \\
\hline 30 & CJ 2 S 230* & 23.20 & 12.13 & 11.07 & 47 \\
\hline 40 & CJ 3 S 240* & 23.20 & 12.98 & 10.22 & 44 \\
\hline 50 & CJ 6 S $250^{*}$ & 23.20 & 15.05 & 8.15 & 35 \\
\hline & ** $\quad-$ serial dilution $10^{-4}$ \\
\hline \multicolumn{6}{|l|}{$\mathrm{M}_{\mathrm{CBM}}$} \\
\hline $\mathrm{M}_{\mathrm{CB}}$ & amoun & on & & heav & \\
\hline
\end{tabular}

and approximately $59 \%$ had absorptive efficiency more than $50 \%$. Thus, many bacterial isolates readily absorbed lead. Isolates that exhibited a higher absorptive capability was found in NSC. Also located in its vicinity were depots of Caltex and Petron that may contribute to lead contamination. Two isolates, PN4 S 230 and PN2 S 240, from NSC had the highest absorptive efficiency of $94 \%$ and $92 \%$, respectively. This was followed by PJ1 S 230 and PM2 S 
Table 2. Summary of results on the absorptive efficiency of lead-resistant bacterial isolates grown in MS agar with different concentration (ppm) obtained from marine sediments of Iligan Bay

\begin{tabular}{|c|c|c|c|c|c|}
\hline $\begin{array}{l}\text { Heavy metal } \\
\text { concentration } \\
\mathrm{Pb}\left(\mathrm{NO}_{3}\right)_{2} \text { in } \\
\mathrm{Mg} / \mathrm{ml} \text { in } \mathrm{MS} \\
\text { agar used }\end{array}$ & $\begin{array}{l}\text { Heavy metal- } \\
\text { resistant } \\
\text { bacterial isolate }\end{array}$ & $\begin{array}{l}\text { Total amount } \\
\text { of } \mathrm{Pb}(\mu \mathrm{g}) \text { in } \\
\text { culture broth } \\
\text { at start }\end{array}$ & $\begin{array}{c}\text { Amount of } \mathrm{Pb} \\
\text { left in culture } \\
\text { broth in } \mu \mathrm{g} \\
\left(\mathrm{M}_{\mathrm{CBM}}-\mathrm{M}_{\mathrm{CB}}\right)\end{array}$ & $\begin{array}{c}\text { Amount of } \\
\text { metal absorbed } \\
\text { by the bacterial } \\
\text { isolate }(\mu \mathrm{g})\end{array}$ & $\begin{array}{c}\text { Absorptive } \\
\text { Efficiency } \\
(\%)\end{array}$ \\
\hline \multirow{3}{*}{10} & $\mathrm{MVC} / \mathrm{MCCI}$ & & & & \\
\hline & PM4 S $310^{* *}$ & 250.24 & 112.44 & 137.80 & 55 \\
\hline & PM6 S $310^{* *}$ & 250.24 & 82.70 & 167.54 & 66 \\
\hline \multirow[t]{2}{*}{20} & PMI S 220* & 250.24 & 100.51 & 149.73 & 59 \\
\hline & PM6 S 320** & 250.24 & 233.56 & 16.68 & 6 \\
\hline \multirow[t]{5}{*}{40} & PMl S $340^{* *}$ & 250.24 & 90.53 & 159.71 & 63 \\
\hline & PM3 S 340** & 250.24 & 122.03 & 128.21 & 51 \\
\hline & PM4 S 240* & 250.24 & 183.52 & 66.72 & 26 \\
\hline & PM6 S 240* & 250.24 & 184.50 & 65.74 & 26 \\
\hline & PM8 S $340^{* *}$ & 250.24 & 145.17 & 105.07 & 41 \\
\hline \multirow[t]{6}{*}{50} & PM1 S $250^{*}$ & 250.24 & 198.60 & 51.64 & 20 \\
\hline & PM2 S $250^{*}$ & 250.24 & 22.61 & 227.63 & 90 \\
\hline & PM4 S 350** & 250.24 & 107.84 & 142.40 & 56 \\
\hline & PM5 S 250* & 250.24 & 182.04 & 68.20 & 27 \\
\hline & PM6 S 250* & 250.24 & 175.90 & 74.34 & 29 \\
\hline & NSC & & & & \\
\hline \multirow[t]{2}{*}{10} & PN3 S $210^{*}$ & 250.24 & 159.16 & 91.08 & 36 \\
\hline & PN4 S $210^{*}$ & 250.24 & 216.00 & 34.24 & 13 \\
\hline \multirow[t]{3}{*}{20} & PN2 S $220^{*}$ & 250.24 & 246.24 & 4.00 & 1 \\
\hline & PN3 S 220* & 250.24 & 235.02 & 15.22 & 6 \\
\hline & PN6 S 220* & 250.24 & 104.42 & 145.82 & 58 \\
\hline \multirow[t]{5}{*}{30} & PN2 S 230* & 250.24 & 214.50 & 35.74 & 14 \\
\hline & PN3 S 230* & 250.24 & 65.20 & 185.04 & 73 \\
\hline & PN4 S 230* & 250.24 & 14.62 & 235.62 & 94 \\
\hline & PN5 S 230* & 250.24 & 115.91 & 134.33 & 53 \\
\hline & PN6 S $330^{* *}$ & 250.24 & 25.82 & 224.42 & 89 \\
\hline & PN2 S $240^{*}$ & 250.24 & 18.13 & 232.11 & 92 \\
\hline \multirow{3}{*}{$\begin{array}{l}40 \\
50\end{array}$} & PN5 S $250^{*}$ & 250.24 & 36.03 & 214.21 & 85 \\
\hline & PN6 S 250* & 250.24 & 48.80 & 201.44 & 80 \\
\hline & Jacinto & & & & \\
\hline & Colorsteel & 250.24 & 69.03 & 181.21 & 72 \\
\hline $\begin{array}{l}10 \\
30\end{array}$ & $\begin{array}{l}\text { PJ2 S } 210^{*} \\
\text { PII S } 230^{*}\end{array}$ & 250.24 & 20.41 & 229.83 & 91 \\
\hline- & $\frac{\text { PJ1 S 230* }}{\text { al dilution } 10^{-3}}$ & & & & \\
\hline$* *$ & al dilution $10^{-4}$ & & & & \\
\hline $\mathrm{M}_{\mathrm{CBM}}$ & $\begin{array}{l}\text { erage amount of } \\
\text { cterial incubation. }\end{array}$ & heavy metal & in culture brot & th supernatant aft & er 48 hours \\
\hline $\mathrm{M}_{\mathrm{CB}}$ & rage amount of $\mathrm{m}$ & & ot supplemel & vith heavy $\mathrm{m}$ & \\
\hline
\end{tabular}


Table 3. Summary of results on the absorptive efficiency of mercury-resistant bacterial isolates grown in MS agar with different concentration (ppm) obtained from marine sediments of Iligan Bay

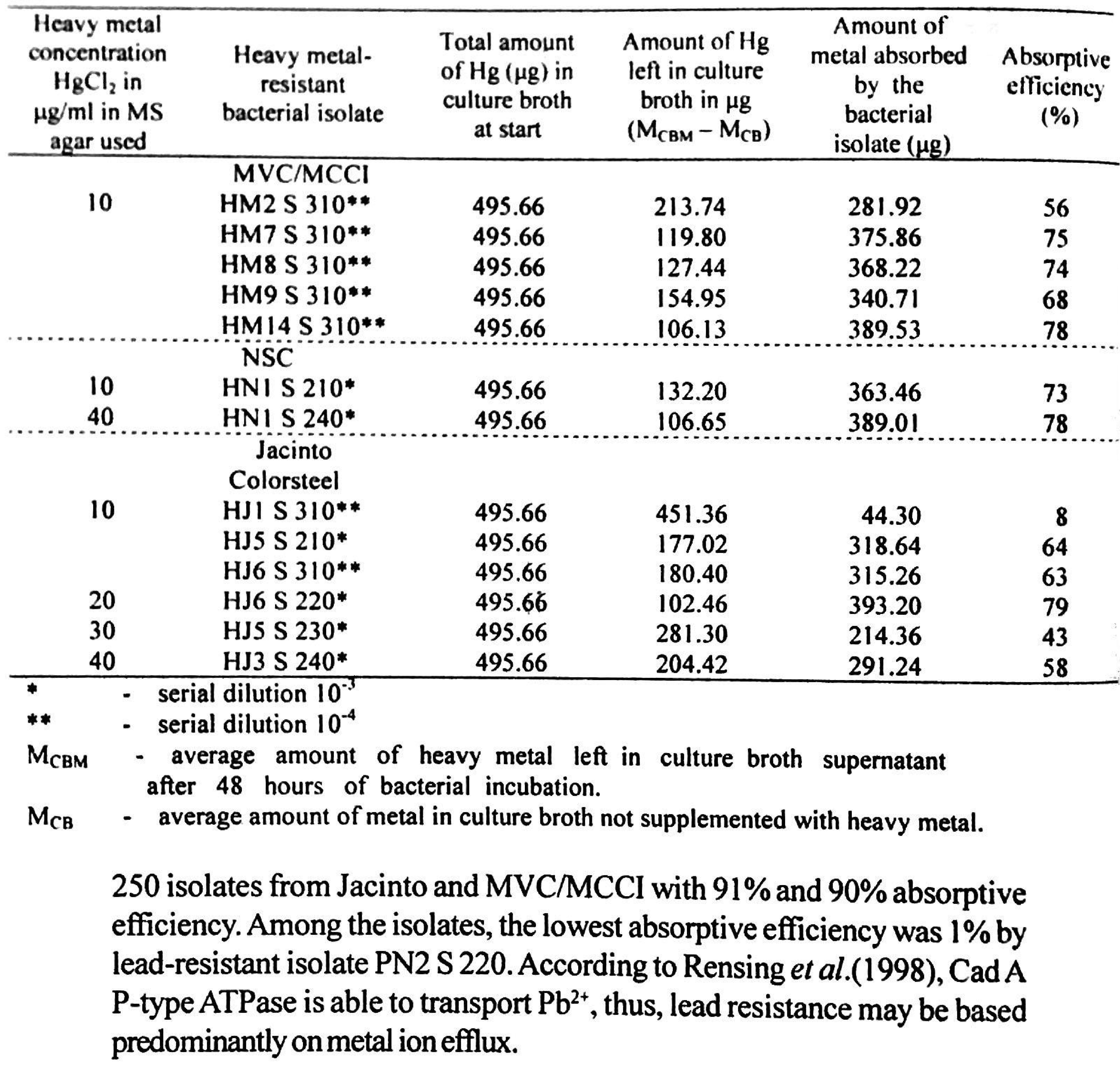

Mercury uptake

Eleven out of 13 mercury-resistant isolates reached more than $50 \%$ absorptive efficiency. Total amount of Hg ion used for biosorption was 495.66 $\mu \mathrm{g}$ (Table 3). Two of the sampling sites (MVC/MCCI and NSC) have been 
found with bacterial isolates with similarly metal uptake at $78 \%$. Dumancas(1977) reported that bacterial isolates from MVC/MCCI effluents have high levels of $\mathrm{Hg}$ concentration due to improper disposal of waste products. Bacterial isolate HJ6 S 220 had the highest metal uptake at 79\%. The low percentage of absorptive efficiency of mercury-resistant bacterial isolates may be due to the conversion of mercury by mercuric reductase enzyme. This enzyme reduces $\mathrm{Hg}^{2+}$ to $\mathrm{Hg}^{0}$ and perhaps volatilizes from the incubation medium(Izaki et al., 1985).

\section{Identification of heavy metal-resistant bacterial isolates}

Identification of heavy metal-resistant bacteria was limited to bacterial isolates which had higher absorptive efficiency. Ten isolates were chosen for identification. Isolates 1, 2, 3 and 4 were lead-resistant and had more than $90 \%$ absorptive efficiency. Isolates 5,6 and 7 which had more than $75 \%$ absorptive efficiency for cadmium were chosen as well as isolates 8,9 and 10 which had more than $78 \%$ absorptive efficiency for mercury. Table 4 showed that isolate 4 (PN2 S 240), 5 (CM1 S 210) and 10 (HN1 S 240) were closely related to genus Chryseomonas and isolates 6(CM6 S 210), 7(CN3 S 250) and 9 (HJ6 S 220) to genus Enterobacter. Isolate 8 (HMN S 310), a Gram negative coccobacilli was identified as Pseudomonas species. On the other hand, Gram positive isolates 1 (PN4 S 230), 2 (PJ1 S 230) and 3 (PM2 S 250) were confirmed as Bacillus species because of the presence of spores and growth in the presence of oxygen.

\section{Chryseomonas species}

Chryseomonas species were found in MVC/MCCI and NSC effluent outlets. Their absorptive efficiencies were high for three different heavy metals: 96\% for cadmium (Chryseomonas sp.2), 92\% for lead (Chryseomonas $\mathrm{sp} .1$ ), and $78 \%$ for mercury (Chryseomonas sp.3). In a collaborative study conducted by Shahamat et al.(1996), Chryseomonas luteola (strain MGF48) was very efficient in taking up heavy metals such as uranium, lead, cadmium, copper, nickel, silver and chromium. The cadmium uptake was $57.50 \mathrm{mg} / \mathrm{g}$ dry cells and lead uptake was $34 \mathrm{mg} / \mathrm{g}$ dry cells in a solution containing 100 $\mathrm{mg} / \mathrm{l}$ of these metals. Comparing the results of this study, amount of cadmium absorbed by Chryseomonas sp. 2 was $22.75 \mu \mathrm{g}$ from $23 \mu \mathrm{g}$ solution of $\mathrm{Cd}$ 
Table 4. Summary of results of the API $20 \mathrm{E}$ tests on the Gram-negative heavy metalresistant bacterial isolates obtained from lligan Bay

\begin{tabular}{|c|c|c|c|c|c|c|c|c|}
\hline \multirow{2}{*}{ Tests } & \multirow{2}{*}{ Substrates } & \multicolumn{7}{|c|}{ Isolate Number } \\
\hline & & 4 & 5 & 6 & 7 & 8 & 9 & 10 \\
\hline ONPG & $\begin{array}{l}\text { Ortho-nitro- } \\
\text { phenyl- } \\
\text { galactoside }\end{array}$ & - & - & + & + & - & + & - \\
\hline $\mathrm{ADH}$ & arginine & + & + & + & - & + & + & + \\
\hline LDC & lysine & - & - & - & - & - & - & - \\
\hline ODC & ornithine & - & - & + & - & - & + & - \\
\hline CIT & $\begin{array}{l}\text { Sodium } \\
\text { citrate }\end{array}$ & + & + & + & + & + & + & + \\
\hline $\mathrm{H}_{2} \mathrm{~S}$ & $\begin{array}{l}\text { Sodium } \\
\text { thiosulphate }\end{array}$ & - & - & - & - & - & - & - \\
\hline URE & urea & - & - & - & - & - & - & - \\
\hline TDA & Tryptophane & - & - & - & - & - & - & - \\
\hline IND & Tryptophane & - & - & - & - & - & - & - \\
\hline VP & $\begin{array}{l}\text { Sodium } \\
\text { pyruvate }\end{array}$ & + & + & + & + & + & + & + \\
\hline GEL & $\begin{array}{l}\text { Kohn's } \\
\text { gelatin }\end{array}$ & + & + & + & - & - & - & + \\
\hline GLU & glucose & + & + & + & + & - & + & + \\
\hline MAN & mannitol & - & - & - & + & - & - & - \\
\hline INO & inositol & - & - & + & - & - & - & - \\
\hline SOR & sorbitol & - & - & + & + & - & + & - \\
\hline RHA & rhamnose & + & - & + & + & - & + & + \\
\hline SAC & sucrose & + & - & + & - & - & + & + \\
\hline MEL & melibiose & + & + & + & + & - & + & + \\
\hline AMY & amygdalin & - & - & + & - & - & + & - \\
\hline ARA & arabinose & + & + & + & + & - & + & + \\
\hline ox & on filter paper & - & - & - & + & - & - & - \\
\hline Bact & rial genera & $\begin{array}{c}\text { Chryseo- } \\
\text { monas } \\
\text { sp. } 1 \\
\end{array}$ & $\begin{array}{c}\text { Chryseo- } \\
\text { monas } \\
\text { sp. } 2 \\
\end{array}$ & $\begin{array}{c}\text { Entero- } \\
\text { bacter } \\
\text { sp.1 } \\
\end{array}$ & $\begin{array}{c}\text { Entero- } \\
\text { bacter } \\
\text { sp.2 }\end{array}$ & $\begin{array}{l}\text { Pseudo- } \\
\text { Inonas } \\
\text { sp. }\end{array}$ & $\begin{array}{c}\text { Enterobac- } \\
\text { ter } \\
\text { sp. } 3 \\
\end{array}$ & $\begin{array}{l}\text { Chrysea } \\
\text { monas } \\
\text { Sp. } 3\end{array}$ \\
\hline
\end{tabular}

(Table 1) and amount of lead absorbed by Chryseomonas sp.1 was 232.11 $\mu \mathrm{g}$ from $250.24 \mu \mathrm{g}$ solution of $\mathrm{Pb}$ (Table 2) which indicate that these isolates are more efficient in metal uptake.

Pseudomonas species

A Gram negative bacteria ; Pseudomonas sp. which was isolated form MVC/MCCI had absorptive efficiency of $78 \%$ for mercury (Table 3). Bacteria belonging to these species could potentially be used for environmental purposes 
Table 5. Growth promotion and inhibition of heavy metal-resistant bacteria isolates obtained from marine sediments of Iligan Bay and control bacteria using the filter paper disc diffusion method

Heavy metal-resistant bacterial isolate

Zone of growth
promotion

Zone of inhibition

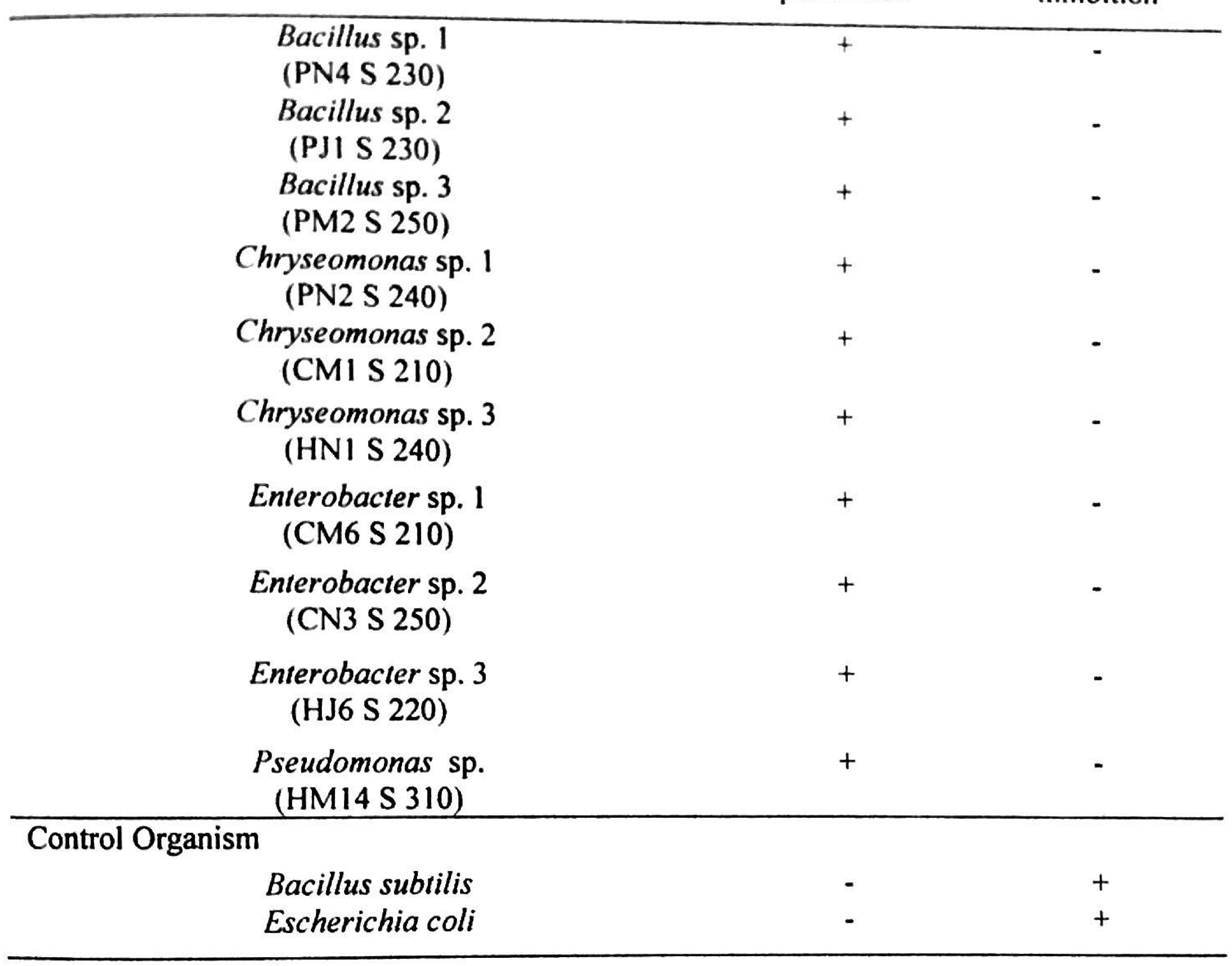

(Bossis et al., 2000). In the study conducted by Canstein et al.(1999) on the removal of mercury from chloralkali electrolysis wastewater, it showed that between 90 and $98 \%$ of mercury was removed by a mercury-resistant bacterial strain of Pseudomonas putida, which indicates that microbial detoxification system for mercury was highly effective.

\section{Enterobacter species}

Enterobacter species were found in each of the three sampling sites. Bacterial isolate, Enterobacter sp. 2 from NSC had the highest absorptive efficiency for cadmium which is $99 \%$ followed by Enterobacter sp. 3 with 
$79 \%$ for mercury and Enterobacter sp. 1 with $76 \%$ for cadmium. Enterobacter cloaca isolated from industrial effluents were previously reported to accumulate or remove $86 \%$ of cadmium (Haq et al. 1999), nickel and vanadium from contaminated effluents (Hernandez et al., 1998).

\section{Bacillus species}

Among the Bacillus species identified, Bacillus sp.1 had the highest absorptive efficiency of $94 \%$ for lead followed by Bacillus $\mathrm{sp} .2$ and Bacillus sp. 3 with $91 \%$ and $90 \%$, respectively (Table 3 ). Bacillus were also studied with regard to their ability to tolerate and accumulate cadmium at concentrations varying from 0 to $100 \mathrm{mg} / \mathrm{l}$ (Boularbah et al., 1992). Results showed an increase in accumulate $\mathrm{Cd}$ in bacteria with increasing $\mathrm{Cd}$ concentration in solution. In another study conducted by Smith (1998), Bacillus subtilis was also able to oxidize $\mathrm{Hg}(0)$ to $\mathrm{Hg}(\mathrm{II})$. Spores of marine Bacillus sp. exhibited a high affinity for $\mathrm{Cu}$ (II). Their great surface area, site density and affinity give Bacillus spores a high capability of binding metals on their surfaces ( $\mathrm{He}$ and Tebo, 1998). This study has established for the first time that Bacillus species are able to absorb lead metal.

\section{Growth promotion and inhibition}

All heavy metal-resistant bacterial isolates exhibited a zone of growth promotion surrounding a filter paper disc impregnated with heavy metals (Fig. 2). The results suggest that heavy metal-resistant bacterial isolates that have the highest absorptive efficiency would best survive or grow in an environment with appropriate concentration of metals and are able to utilize the heavy metals. Control organisms (B. subtilis and $E$. coli) were not highly adapted to environments with heavy metals, thus the zone of inhibition (Fig. 3). This finding of growth promotion has been established for the first time and it can lead to some insights that some bacteria can use heavy metal for energy and growth. Bacteria that are resistant to and grow on metals also play an important role in the biogeochemical cycling of metal ions. This is an important implication of microbial heavy metal tolerance because the oxidation state of heavy metal relates to the solubility and toxicity of the metal itself. In metal-contaminated environments, it has been found that among bacteria present, there is more 


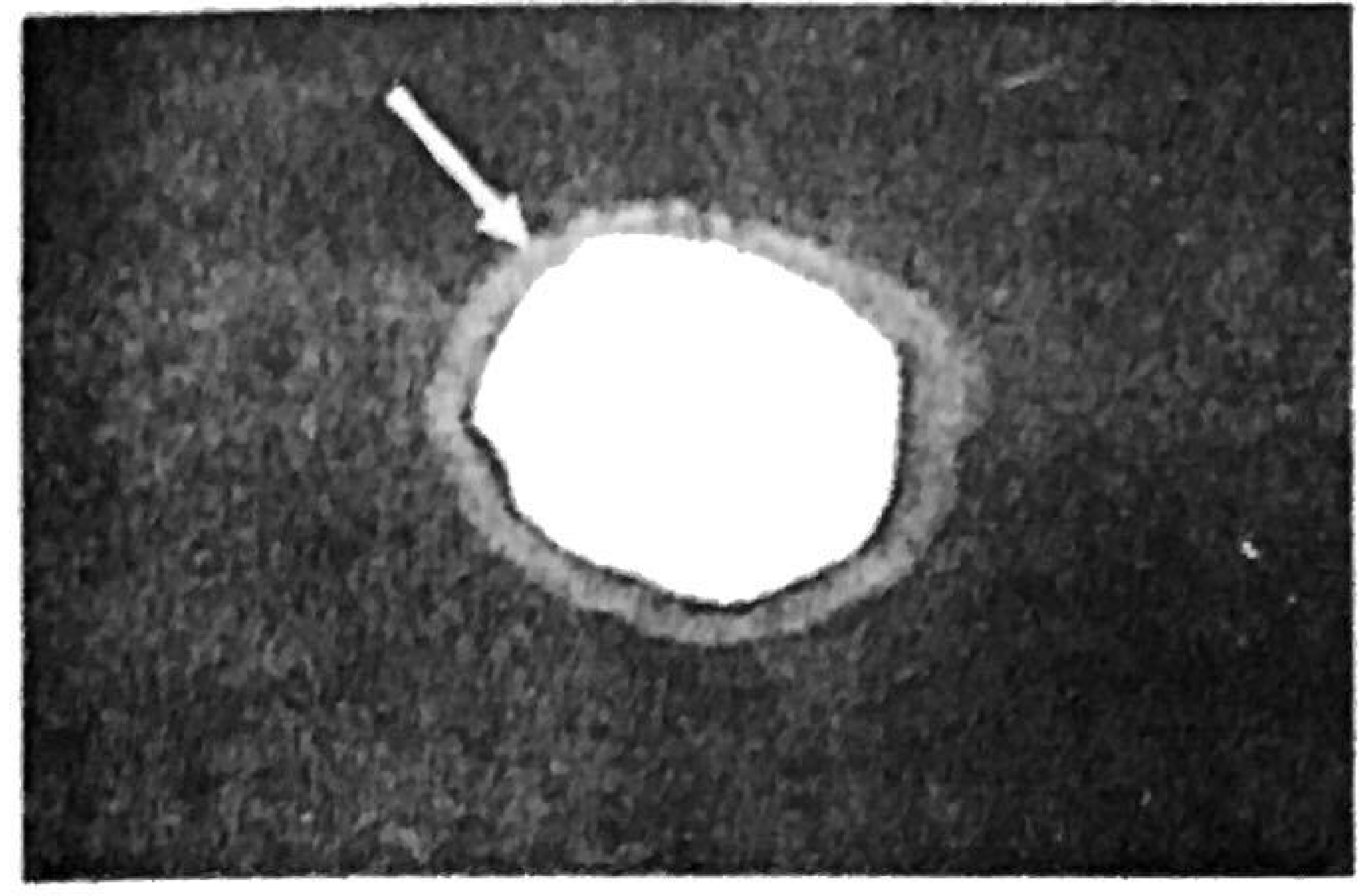

A

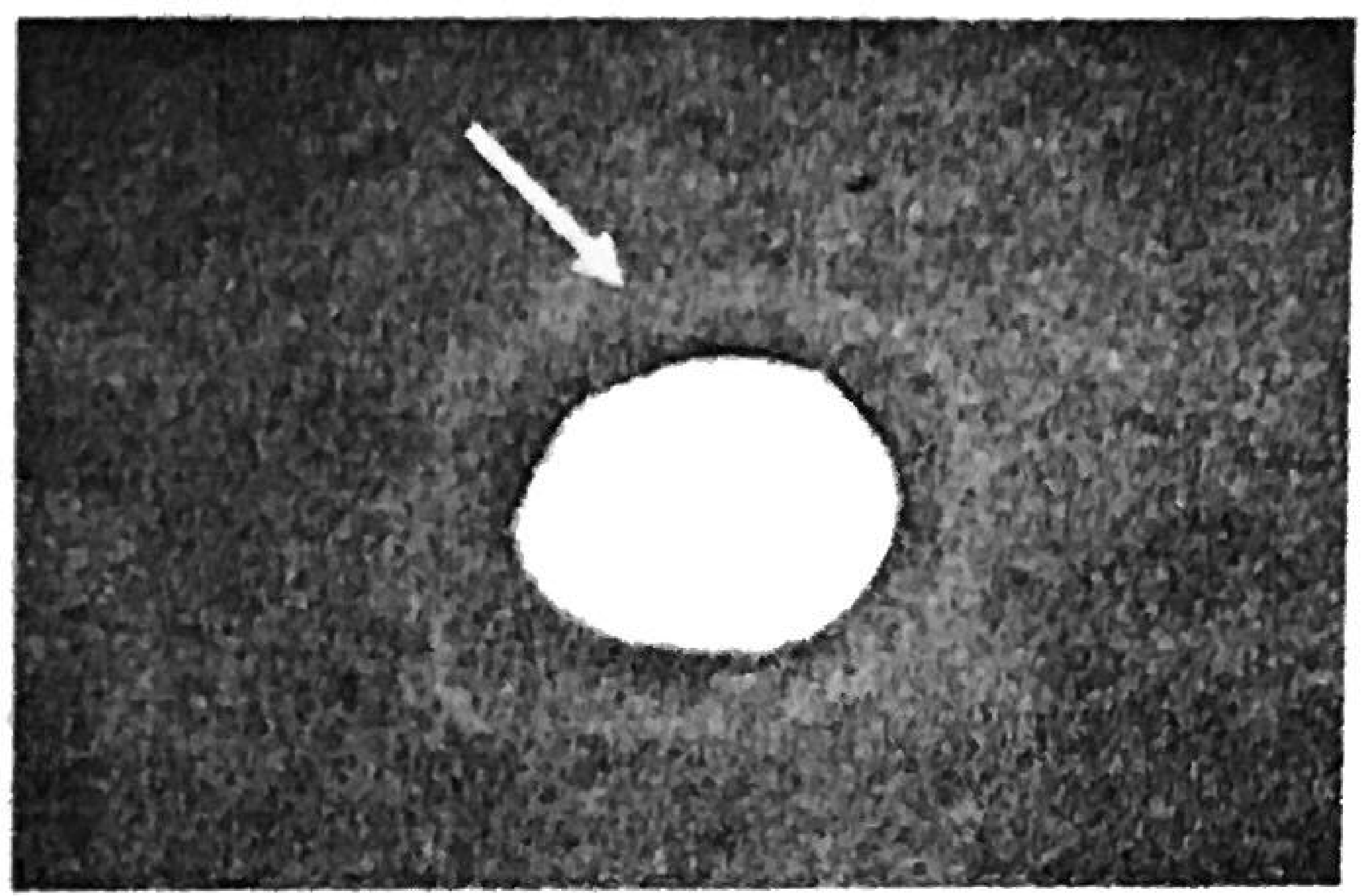

B

Figure 2. Zone of growth promoiton of (A) Enterobacter sp. 2 and (B) Bacillus sp. 1

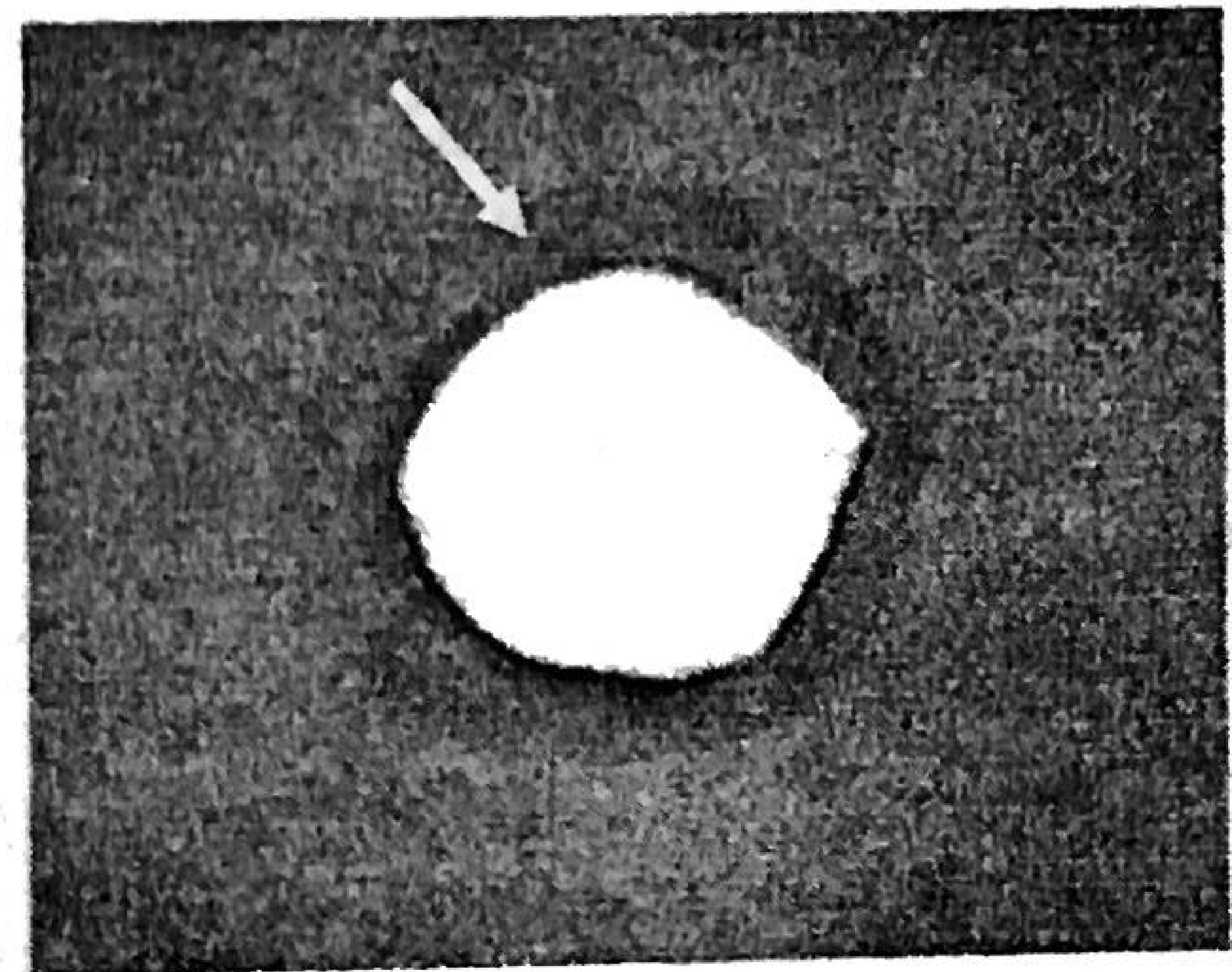

A

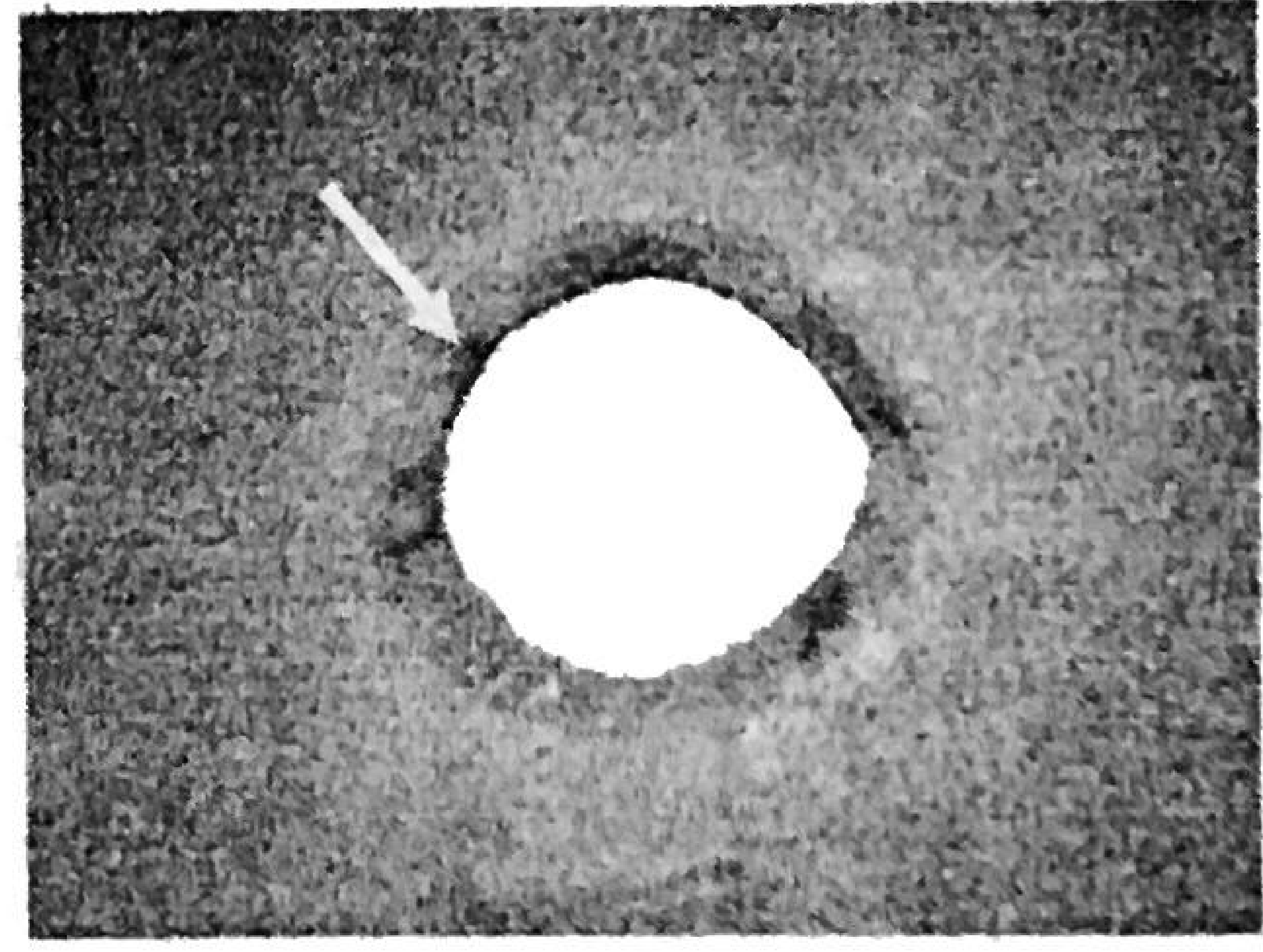

B

Figure 3. Zone of inhibition of (A) B. subtilis and (B) E. coli 
potential for unique forms of respiration(Spain, 2003).

\section{CONCLUSIONS AND RECOMMENDATIONS}

This study was able to isolate 61 heavy metal-resistant bacteria with efficient absorptive capacity. Absorptive efficiency for $\mathrm{Cd}$ and $\mathrm{Pb}$ reached more than $90 \%$ and more than $78 \%$ for mercury. Their presence is helpful in cleaning up the environment by recapturing toxic compounds released from industrial effluents. It is recommended that the bacterial isolates be characterized using 16-S rRNA and determine the effect of environmental factors such as $\mathrm{pH}$, heat, $\mathrm{UV}$ and metabolic inhibitors on metal uptake. Also, bacterial isolates be tested for resistance to other heavy metals and further isolate heavy metalresistant strains as potential tools for bioremediation.

\section{ACKNOWLEDGMENT}

This study was funded by DOST-ESEP Marine Biology Program through the coordination of Ms. June Pereña. Help and support were given by Dr. Carmelita G. Hansel, Dr. Stella Marie M. Doyungan, Dr. Franco G. Teves and Dr. Beverly B. Amparado from DBS at MSU-IIT and Dr. Myrna S. Mahinay from the Dept. of Chemistry at MSU-IIT.

\section{LITERATURE CITED}

BAUER, A.W., W.M.M. KIREY, J.C. SHERRIS and M. TRUYA. 1966. Antibiotic susceptibility testing by a standardized single disk method. American Journal Clinical Pathology 45:493.

BOULARBAH A., J. L. MOREL, G. BITTON and A. GUCKERT. 1992. Cadmium biosorption and toxicity to six cadmium-resistance gram positive bacteria isolated from contaminated soil. Environmental Toxicology and Water Quality 7:237246.

BOSSIS E., P. LEMANCEAU, X. LATOUR and L. GARDAN. 2000. The taxonomy of Pseudomonas fluoresens and Pseudomonas putida: current status and need for revision. Agronomie 20:51-63. 
CANSTEIN H.V., Y.LI, K.N. TIMMINS, W.D. DECKER and L.W. DOBLER. 1999. Removal of mercury from chloralkali electrolysis wastewater by a mercury-resistant Pseudomonas putida strain. Applied and Environmental Microbiology 65:52795284.

CRAIS P.J. and J.M. WOOD. 1991. Environmental Lead. Academic Press. New York.

HAQ R., S.K. ZAIDI and A.R. SHAKOORI. 1999. Cadmium-resistant Enterobacter cloaca and Klebsiella sp. isolated from industrial effluents and their possible role in cadmium detoxification. World Journal of Microbiology and Biotechnology 15:283-290

HE L.M. and B.M. TEBO. 1998. Surface charge properties of and $\mathrm{Cu}(\mathrm{II})$ adsorption by spores of the marine Bacillus sp. strain SG-1. Applied and Environmental Microbiology 64:1123-1129.

HERNANDEZ A., R.P. MELLADO and J.L. MERTINEZ. 1998. Metal accumulation and vanadium-induced multidrug resistance by environmental isolates of Escherichia hermannii and Enterobacter cloaca. Applied and Environmental Microbiology 64:4317-4320.

IZAKI, K., T.AOKI and H. TAKAHASHI. 1985. Degradation of organomercurials in Bacillus aureus. Agricultural Biological Chemistry 16:1-8

MAMARIL J., E.T. PANER and L.C. TRINIDAD. 1993. Biodecontamination of mercury, lead and cadmium by selected strains of Rhizobium. Transactions National Academic Science 15:163-177.

MC CALLA T.M. 1940. Cation adsorption by bacteria. Journal of Bacteriology 40:2332.

NAKAHARA H., T. ISHIKAWA, Y. SARAL and I. KONDO. 1977. Distribution of resistance to metals and antibiotics of staphylococcal strains in Japan. Zentralbl. Bakteriol. Mikrobiol 237:470-476.

NEIS D.S. and S. SILVER. 1995. Ion efflux systems involved in bacterial metal resistance. Journal of Industrial Microbiology 14:186-199.

PERRY R.D. and S, SILVER. 1982. Cadmium and manganese transport in Staphylococcus aureus. Plasmid 1:38-51.

RENSING C., Y. SUN, B. MITRA and B.P. ROSEN. 1998. Pb(II) translocating P-type ATPase. Journal of BiolChemistry 273:32614-32670.

SHAHAMAT M., F. MALEKZADEH., H. GHAFOURIAN, M. LENIN., C. GRIM. 1996. Accumulation of heavy metals by bacterium isolated from electroplating. Biotechnology Risk Assessment Symposium. Ontario, Canada. pp.320-334. 
SMITH T., K. PITTS, J.A. MCGARVEY and A.O. SUMMERS. 1998. Bacterial oxidation ofm ercury m etalvapor, $\mathrm{Hg}(0)$. Applied and Environmental Microbiology 64:1328. 1332.

SPAIN A. 2003. Implications of microbial heavy metal tolerance in the environment, vol.2. University of Oklahoma. USA.

TSEZOS M. and J.P. BELL. 1989. Comparison of the biosorption and adsorption of hazardous organic pollutants by live and dead biomass. Water Research 23:561. 568

TSEZOS M. and D.M. KELLER. 1993. Adsorption of radium 226 by biological origin absorbents. Bioengineering 25:201-215.

WITTE, W., L. GREENE and E. CHEN. 1986. Resistance to mercury in chromosomally resistant Staphylococcus aureus. Antimicrobial Agents and Chemotheraphy. USA 